\title{
Women directors in Hungarian cinema 1931-44
}

\author{
Gábor Gergely* \\ School of Film and Media \\ University of Lincoln
}

\begin{abstract}
Virtually nothing has been written about Hungary's three pioneering women film directors in English or Hungarian. The only mentions of the three directors and their films are found in throwaway comments in Hungarian works of film history, in an incorrect entry in a national filmography (Varga 1999), and in a dismissive article of 1985, which ignores one of the three films altogether. This article seeks to make up for this critical and historiographical oversight. This article asks why did these filmmakers succeed; and why and how did they succeed in an industry so utterly dominated by men? The other aim of this article is to move beyond discovery, and read the films in their context to assess the contribution they made to national cinema and the dominant nationalist discourse in interwar and wartime Hungary.
\end{abstract}

Keywords: women filmmakers; Hungarian cinema; popular film; film industry; anti-Semitism

This article on women directors in Hungarian cinema in the period between 1931 and 1944 is intended as a contribution to the work of discovery of the histories of women filmmakers (Gaines 2004, 113). It aims to fill gaps in our knowledge of Hungarian film history, and thus question the version of the cinematic past that excludes women's stories. It also hopes to bring attention to an overlooked aspect of Hungarian film history, not only in order to show that the production context is more complex than hitherto thought (not all of the women directors discussed in this article can be said to have challenged the dominant discourse of their period), but also to plug a gap in scholarship.

Three women directed feature films in Hungary between the introduction of sound in 1931 and the end of wartime film production in 1944. They were Mária Balázs (Pókháló/Spider's Web, 1936), Klára Riedl (Isten tenyerén/In the Palm of God, 1939) and Klára Tüdős (Fény és árnyék/Light and Shadow, 1943). ${ }^{\mathrm{i}}$ That three women did direct films in this period is all the more remarkable as so called traditional family values dominated Hungarian concepts of womanhood in the early twentieth century. This article asks why did these filmmakers succeed; and why and how did they succeed in an industry so utterly dominated by men? The other aim of this article is to move beyond discovery, and read the films in their context to assess the contribution Balázs, Riedl and Tüdős made to national cinema and the dominant nationalist discourse in interwar and wartime Hungary.

The remarkable achievements of Balázs, Riedl and Tüdős should be understood within the context of the vibrant and competitive film industry of the early 1930s and the subsequent imposition of complete state control, the implicit ban on free competition and the explicit ban on Jewish participation in filmmaking. I am not arguing that it was the exclusion of Jewish Hungarians from the sector that paved the way for women filmmakers to emerge. Balázs made her film before the racist purge of the industry. This shows that we should be looking for other explanations. This article argues that moments of political, economic and technological upheaval, moments in which the established structures of the film industry undergo crucial transformations, play an important role in the emergence of women directors.

This article aims to illuminate practices of exclusion in the context of Hungarian cinema, scholarship and collective memory. Although this study deals with the narrow context of 1930s-40s Hungary, it is also intended to contribute to developing a greater understanding of the stories of women directors in other male-dominated centres of film production.

\footnotetext{
*Email: ggergely@lincoln.ac.uk
} 
I rely heavily on the official film industry bulletin Magyar Film, which was published between December 1938 and November 1944 by the Hungarian Chamber of Film and Dramatic Arts, the quasi non-governmental organization established to oversee the film sector, control its output and regulate its processes. I use this primary source for two reasons. First, the story of pre-1945 Hungarian women filmmakers is woefully under-researched. The overlooked and fragmented film texts that survive bear testament to the lack of critical interest and a general absence of women's cinema from the collective (cultural) consciousness, which indicates an indefinite postponement of this issue in the specific context of Hungarian film scholarship (see Gaines 2004). Second, the little that has been written about Balázs, Riedl and Tüdős is the product of the state socialist era (e.g. Nemeskürty 1965; Erdélyi 1985), and as such is inflected by the interests of the state, and in particular the official ideology as applied to culture and cultural history in Hungary at the time of writing, or the question of the two presents of women's film history: the time written about, and the time of writing (Gaines 2004, 115).

\section{From entertainment industry to state-controlled cinema}

The three films span perhaps the most hectic years of Hungarian cinema. The fledgling domestic industry had grown rapidly in 1931-35, thanks in no small part to writer-producer-director and future émigré István Székely (Steve Sekely). Home-grown successes such as Hyppolit a lakáj/Hyppolit the Butler (Székely, 1932) and Meseautó/Car of Dreams (Béla Gaál, 1934) were beginning to attract an audience, despite a market dominated by imports. However the collapse in 1934 of the production company City had sent shockwaves through the sector.

While foreign imports were a relatively safe bet, domestic productions could bankrupt investors. In addition, the market was exposed to state meddling. Cinema remained primarily an exhibitor's business in Hungary through the silent era. After the advent of sound, partly due to protectionist quotas introduced in the early 1930s and in part owing to the broader trend of rising demand for domestic product in the early sound period, a genuine national film industry emerged. 1936, the year Spider's Web was made, saw a marked slowdown in the rate of growth. This was due to the failure of the Hungarian economy to shake off the effects of the Great Depression. The main obstacles to balanced growth in the sector were high rates of unemployment coupled with the continuing recessionary effects of the Trianon Treaty, which had ordered two-thirds of pre-1918 Hungarian territories to be annexed to neighbouring countries, in the process cutting off major economic centres. Still, the film business proved itself fairly recession-proof. Figures from the Hungarian film institute ${ }^{\mathrm{ii}}$ show that in 1937 a total of 37 films were made, as overall output more than doubled in the two years to 1937. Hungary successfully maintained double-figure growth in film output in every year of the 1930s until 1938, when output dropped for reasons I explain below.

With such clear indication of a recession-proof business with the potential for sharp growth, new pressure began to mount on the Hungarian Government to complete the process, begun with the redistribution of cinema licences in the early 1920 s, of eliminating competition from the industry and mounting an asset grab on what was seen as 'Jewish property' in the sector. ${ }^{\text {iii }}$ In 1938 the Hungarian Government passed Act 15 of 1938, which restricted Jewish Hungarians' right to participate in the economy. ${ }^{\text {iv }}$ It had a major impact on the film industry, where its provisions were most rigorously enforced. It set a $20 \%$ ceiling for Jewish presence in the sector, with Jewish Hungarians banned outright from all above-the-line positions. It stipulated that all industry players must apply for membership in the newly established state-backed industry regulator, the Hungarian Chamber of Film and Dramatic Arts. Failure to secure membership was an effective banishment from the profession. With a number of key market players affected, output fell immediately, by $10 \%$ compared to $1937 .^{v}$

A second anti-Jewish act of Parliament, Act 4 of 1939, followed in May next year. Domestic and German pressure for further anti-Jewish measures in exchange for Hitler's support for Hungarian territorial claims against neighbouring countries was a contributing factor (Braham 2000, 23-5; 
Tönsmeyer 2008, 92). It was also hoped that stricter measures limiting the involvement of Jewish Hungarians in filmmaking would help open up the German market for Hungarian films. The 1939 antiJewish law lowered the ceiling of Jewish participation to $6 \%$ across the industry and imposed further restrictions by extending the full ban to other segments (e.g. supporting actors). It further ruled that those who were 'Jews' under the law could account for no more than $6 \%$ of any single segment of the industry, amounting to a full ban on new Jewish Hungarian members of the Chamber. The cumulative effect of the two acts, and the raft of industry regulation that accompanied them, was a further $21 \%$ drop in output.

A racial law was passed in 1941, banning sexual relations between those who were 'Jews' in the eyes of the law, and those who were not. The state made forays into genocide, too, when it delivered tens of thousands of Jewish Eastern European refugees, as well as a large number of Jewish Hungarians, for destruction by the SS in Kamenets-Podolsk in 1941 (Braham 2000, 33-4). The film industry was purged of the last few Jewish Hungarians under Act 15 of 1941. Although the industry spoke of a target of film self-sufficiency (see Magyar Film June 1, 1940; and September 27, 1941), this was wildly unrealistic: domestic output accounted for 24\% of the 154 films released in the 1941/42 season (Magyar Film August 10, 1942, 10). However, due to a number of initiatives designed to train new personnel, ${ }^{\text {vi }}$ the sector had recovered from the anti-Jewish purge. Domestic production reached a historic peak of 51 films in 1943.

The film business, still nominally in private hands, was under full state control by 1943. In addition to the law-given means of restricting participation within the sector, censorship had been in place in the film sector since 1920 (Záhonyi-Ábel 2013, 90). The censors were fairly tolerant in some way, but were quick to ban anything they thought might threaten the interests of the state. ${ }^{\mathrm{vii}}$ All proposed projects had to clear the hurdle of a pre-production vetting process. Studio time in the state-owned production facilities was allocated by a state-appointed committee. Entry into the industry was thus barred to anyone who failed to meet the requirements of the state (Magyar Film March 10, 1942, page 1). Projects that failed to tick the boxes were denied funding, access to production facilities or distribution. At every stage filmmakers had to tread carefully and relied entirely on the goodwill of state-appointed industry bosses.

\section{Spider's Web: money opens the doors}

As underlined by the discussion of the production context above, it seems remarkable that a woman succeeded to break into the top ranks of a male-dominated industry in 1936. The industry output was rarely anything other than firmly patriarchal. Take Tavaszi zápor/Spring Downpour (Fejös, 1932). The film, incidentally scripted by a woman, Ilona Fülöp, told the story of a virgin whose death is the direct consequence of her willing surrender to a seducer who has no intention of marrying her. Box office sensation Car of Dreams is about the power of a luxury car to cause a woman to fall in love with its owner. Even in those films where female characters make seemingly independent decisions about who they should marry, they seem to decide, on their own and out of true love, to fall for the very suitor chosen for them by their parents. Spider's Web is no exception. Erdélyi tells the story of how Balázs came to make this film, based on an interview with the director published in Film magazine in summer 1936 (1985, 70-74). The interview reveals that Balázs was of independent means and had an interest in the arts. She travelled extensively and studied filmmaking abroad. On her return to Hungary she decided to fund a film herself, which she would also direct (ibid.). The industry welcomed the investment, particularly in a year in which productions struggled to get off the ground, and Balázs realized her ambition.

Spider's Web tells the story of two parallel romances. Irén (Romola Németh) is a high achieving school leaver. She has finished her written exams, and only orals are left to complete. Her teacher, Dr Benjámin (Zoltán Szakáts) suffers from a terror of women, having observed the cannibalistic behaviour 
of female spiders. Nonetheless, he is in love with his bright pupil, Irén. Benjámin's colleague at the school, Dr Marischell (Ella Gombaszögi) is in turn besotted with the out-of-work actor Fonyódi (Imre Ráday). She feeds him regularly and royally, and promises to secure him a permanent theatre contract through her influential brother. He, however, has eyes only for Irén, who is younger, richer and prettier than her matronly teacher. Irén's friend, Manci (Mici Erdélyi) is a dim but lively girl whose only ambition is to become a soubrette. Fonyódi and Manci strike a sordid deal: if Manci helps Fonyódi get close to Irén, he will get her the soubrette role she covets. Irén, thus delivered into the path of temptation, almost yields to Fonyódi's aggressive advances. She flees from the rendezvous, but he blackmails her to visit him once more. To her relief, just as she gets to his dressing room, she overhears a conversation within: Marischell is telling Fonyódi that she has finally secured his contract and nothing now stands between them. Benjámin discovers that Irén had lied about giving extra tuition to Manci, the pretext under which she had left home throughout the summer to go unchaperoned to meetings with Fonyódi. Benjámin is quick to assume a secret dalliance and confronts Irén. She breaks down and confesses how in her naiveté she had nearly yielded to the seduction of a career on the stage. Irén's budding sexuality thus nipped, Benjámin forgives her and decides to marry her.

This summary illustrates that the film in no way constitutes a challenge to male power. I pick out the crucial details to elaborate this point. In an early scene of the film, Irén entertains her parents' guests by accompanying herself on the piano. Her song is briefly interrupted, when her mother tells a guest in a stage whisper that Irén is not formally trained, she simply takes occasional lessons from a family friend. Her performance is then not the manifestation of Irén's suitability for the stage, which would imply easy virtue. Rather, this is a young lady's demonstration of the skills of a well-brought up young woman. By contrast, we see Manci rehearsing her song with her chorus girls. We are left in no doubt: a career on the stage is next door to prostitution. Elsewhere in the film Benjámin explicitly likens women to female spiders. He asserts that females feed on the male, literally in the case of the spiders, and slightly less directly in the case of humans. In an exchange with Marischell, he explains that unless one is careful, the female will bite one's head off. Indeed, at one point we see through Benjámin's eyes as he observes a spider through a microscope. In his mind's eye Irén's face replaces the arachnid in the middle of a spider's web. It takes little effort to decode the masculinist discourse that roots female sexuality in nature and renders it other by likening it to predatory animal behaviour.

The fear of predatory femininity can be seen running through the film. Benjámin fears Irén, but her naïve indiscretion both justifies his fear and authorizes his assertion of control over her mind and body. Benjámin's marriage proposal in the film's denouement closes not only the film, but also Irén's opportunity for self-determination. Marischell's desperate pursuit of Fonyódi is another familiar patriarchal trope. Gombaszögi had a commanding physique, complemented by a doe-eyed face framed by 1920s curls. This gave her an air of comically anachronistic spinsterish frustration. Her characters' sexual drive was typically expressed through culinary appetite. A good example is found in Spider's Web. She asks the school caretaker to bring her lunch to the staff room. When he suggests some meat, she demurs. 'No, I don't want any meat... bring me cheese spread,' she says, and with supreme comic timing, she adds '... and salami.' That she should ask for that most phallic of all processed meats can hardly be coincidence. Throughout the film, Fonyódi is clearly repelled by her physically. Much of the humour is intended to come from his careful balancing act: to remain in Marischell's good books to gain access to her kitchen, but to keep her at arm's length so as not to be compelled to propose to her. At the end of the film, it is Fonyódi's punishment for trying to seduce Irén that he has to honour his offer of marriage when Marischell delivers her part of the bargain, the theatre contract. As we can see, Spider's Web cannot be said to resist or subvert the dominant discourse of its age. Its title already implicitly links femininity with predatory sexuality. The resolution of its central problems in no way disrupts the status quo. The male partner's character determines the social status of both new couples. 
Benjámin's respectability lifts Irén out of potential disgrace, and Fonyódi's disreputable profession undermines Marischell's credibility as a teacher.

It is worth pausing here to discuss the film's cast and crew, which was diverse and reflected a film sector in the process of rapid development. The cinematographer was Rezsö Icsey, a relative newcomer to the industry, who would become one of the most prominent cinematographers of the early sound period. The editor was Zoltán Farkas, the most prolific editor of this period, who would become a director of workmanlike melodramas during the war. He had a taste for military uniforms, which he wore when directing (Magyar Film January 15, 1944, page 5), and made one propaganda film, which strikes the viewer with its instantly recognizable Nazi aesthetic. In 1936, however, he was a career beginner, with just five credits under his belt. The script was co-written by Balázs with Endre László, who never wrote another film. The sound engineer Károly Pulváry was also in his debut season, but would rise to prominence in the industry. The music was composed by Sándor László who worked on just one other film. It is plain to see that the film gave vital opportunities for career beginners. This reflects the relatively unsettled nature of the Hungarian industry at this time. It is also clear that the film's creative team included some of the best and brightest of the age: Farkas, Icsey, Pulváry, Ráday, Szakáts and Gombaszögi. Perhaps Balázs was simply lucky, or she was a shrewd judge of talent. Either way, her success is in part due to the qualities of the team she directed. Third, this cast list gives us a snapshot of a vibrant industry in which shared interest in getting the job done, in making profit, perhaps even in making art, meant that a disparate group of professionals from a variety of backgrounds and, as history would presently prove, with a wide variety of political beliefs, worked alongside each other. Some of them would profit from the anti-Jewish measures: Farkas in particular, but male lead Szakáts, in type a close match for the Jewish Ráday, and production manager Béla Lévay would rise to prominence as influential industry figures after 1938. Others would see their careers destroyed. Of this film's cast and crew, Gombaszögi and Ráday would be the chief victims of the ban on Jewish participation in the industry. Ultimately, we can see that for a brief period in the 1930s shared goals and ambitions helped to override ideological differences.

\section{In the Palm of God: co-opted by the radical right}

We know very little about the curious ethnographic documentarist drama In the Palm of God and its director. What little we do know comes from contemporary articles printed in Magyar Film. A badly damaged copy, the only one in existence, was found in Belgrade in 2012. Just under an hour of film survives of the 2,400 metres approved for release by the censor in 1939. Some information has come to light thanks to the work of film archivist Pál Pap. The Hungarian film institute has shown very little interest in the film. This is not because it is uninterested in the era: it recently brought out a special edition DVD of the 1936 ethnographic documentary Hortobágy, a film I come back to later on. The institutional neglect may be explained by the bad condition in which In the Palm of God survives, its lack of stylistic or narrative coherence, the refusal to use stars, and rejection of the period's generic conventions. Although it was promoted heavily at the time of its release, it has fallen into oblivion and has so far attracted the interest only of the community of Mezökövesd, where it had been shot. While a version of the shooting script was found in 2014, scholarship on the film remains limited. Writing in 1965, communist-era Film Institute boss and official state historian Nemeskürty mentions the film in passing as having been made (Nemeskürty 1965, 331); Györgyi Vajdovich declares it lost but suggests it bears no resemblance to the rural films of the wartime industry $(2013,69)$; and there is a brief and incorrect entry on it in Magyar Filmográfia (Varga 1999, 143-44). As we shall see, the film merits more careful attention.

In the Palm of God premiered in Budapest in Uránia, a German-owned prestige theatre, on 21 August, 1939 (Magyar Film August 26, 1939). It is first mentioned in Magyar Film in one of the very first issues. A brief report notes that the film had been in production for five years. The article then 
describes it as a 'film of unusual genre' characterized by 'a new and surprising style, $[\ldots]$ ethnographic and geographical beauty [...] and original narrative' (February 18, 1939, page 14). The few articles that mention the film at this time focus on the length of production, the exceptional nature of the film and its story, and the honesty and ethnographic accuracy of the representation of folk customs (Magyar Film February 8, 1939; Esti Újság April 13, 1940). In short, the film's difference from the run of the mill is emphasized, while the readership is also reassured that although different, the film is still a celebration of all things Hungarian.

In 1939 Magyar Film published a detailed credit list. Riedl is credited as director and scriptwriter (as Mrs Tibor Nagy née Klára Riedl). Perhaps in an attempt to downplay the extent of her contribution, the film was usually referred to as being the brainchild of Imre Huzly, who produced the film and took a scriptwriter's credit. He was a physician ${ }^{\text {viii }}$ and editor of the medical bulletin Orvosi Hirlap. He had a side-line in film through his production and distribution company Auróra, and he used Orvosi Hirlap funds to bankroll the film. He is remembered as one of the first Hungarian film industry figures to talk of a new tradition of 'rural film' (Vajdovich 2013, 68). His credit as scriptwriter is likely to have been a way to boost his share of the takings. We have no reason to doubt that the surviving script was intended as a shooting script, but it has little to do with the finished film. Bearing in mind that shooting scripts required prior approval by a committee of censors, it is possible that the script was meant for the committee's eyes only, and was written to bring the project into line with regulation.

Riedl made In the Palm of God under the supervision of two directors. One of them, Isvtán György, was a senior figure in the radical rightwing Turul Alliance, which campaigned for the expulsion of Jewish Hungarians from cultural life. ${ }^{\text {ix }}$ The other was Huzly's partner in Auróra (Nemeskürty 1965, 331). Three production managers are credited. This might be explained by the lengthy period of production. They included Tibor Nagy (probably the director's husband) and István Lázár, who would go on to direct the Nazi-flavoured propaganda film Viharbrigád/Storm Brigade (1944). The editor was Zoltán Farkas who had also cut Spider's Web. The cinematographers were István Berendik and József Karbán. For both the film was a career re-launch and a first encounter with sound technology. This was a pre-1938 production with no Jewish involvement, attesting to the crew's radical right-wing pedigree.

The film is an unusual representative of the rural film tradition of Hungarian cinema. It lacks stylistic and narrative coherence even if we allow for the missing reels. The film as it survives consists of three distinct parts. The first is a romance set in Budapest. Its protagonist is Kati, ${ }^{\mathrm{x}}$ a girl from the country staying with relatives in the capital. During an outing to the Budapest Castle Kati is separated from her aunt in the crowd that watches the changing of the guard. A cadet escorts her home. Love strikes, and the two begin courting. They go for walks in the hills of Buda. She asks him about his mother, and he tells her about his father. This telling slippage is early indication of a rarely heard critical voice: it is an unmasking of a male-dominated system that is deaf to women, and which constantly reaffirms its own legitimacy via the ceaseless reiteration of the deeds of past men.

This fleeting moment of subversion is immediately drowned out by a sequence suffused with nationalist pathos. This, I argue, is the second distinct part of what survives of the film. It consists of images of the Hortobágy, an emblematic region of Hungary, accompanied by a misty-eyed voiceover. This feels like a late addition to the film, either to bring it into line with the unofficial requirement of images glorifying the countryside, or to extend the running time. This is given weight by the fact that this region would not have been unknown to Kati, native of the neighbouring region of Matyóföld. A knowledgeable ethnographer, which contemporary articles claimed the director was, would not have misrepresented regional geography to this extent. As I shall show, credit for this sequence is probably due to the producer, Huzly.

I believe Riedl's voice, as ethnographer and filmmaker, can be heard most clearly in the third part. Back home in her village Kati waits for the promised arrival of the cadet. In a series of vignettes showing village life as revolving around production and reproduction, we see two suitors vying for her 
affections. Courtship customs are rendered with attention to detail. Kati observes the suitors' advances in good humour, and deflects their approaches with tact and firm resolve. She gives no encouragement to either. Still, they pursue her, and both ask for her hand. She rejects both. The spurned suitors begin a hate campaign. The whole village shuns Kati, and even her two sisters are given the cold shoulder. Although profoundly upset, Kati shows strength and integrity. There is no doubt: the film is made with sympathy for Kati's plight. The courtship customs of the region are shown with an aspiration to ethnographic authenticity, but the focus is on the young woman's experience of the inequality inscribed into tradition. There is evidence that suggests that this is to be attributed to Riedl. We have seen that the script demonstrates a heavy handed nationalism that is absent from those parts of the film that are immediately concerned with ethnographic detail. I argue that the script's vocabulary and style indicated Huzly's authorship. Comparing the scene of Kati giving rendezvous at the same time and place to the two suitors in the film with the corresponding scene in the script shows the difference in emphasis. The script has Kati maliciously arranging for the two suitors to turn up at the same time and place, ensuring confrontation and humiliation. In the finished film, however, Kati has little choice but to accept the rendezvous proposed by each suitor in turn. Sure enough, the two men turn up and find the other approaching the place of the rendezvous. In the script Kati is a coquette. In the film she has to negotiate a treacherous terrain where any false step could leave her branded a harlot.

She acquits herself well, and eventually wins the admiration of her community. She confronts her suitors and convinces them that they were foolish to pursue her when she gave them no encouragement, and that they should take note of the obvious affection that her sisters have for them. Although still harbouring resentment for Kati, the suitors indeed propose to the sisters. For a while Kati remains side-lined. Finally the cadet, now an officer, comes to Kati's village, and asks for her hand. Her father refuses to consent as he had hoped to extend the family farmstead through his daughters' marriages, but Kati's mother overrules him and gives her blessing to the marriage. The film closes with the wedding. We see Kati in full wedding dress pass by a group of women. Where they had sniped maliciously earlier, now one of them says: 'for such a handsome man it was well worth going against the whole village!'xi

It is refreshing to encounter a film from this period that shows the trials and thrills of love from a female perspective. It is not the man fighting for paternal consent that dominates the narrative. Instead the focus is on the female character, her desires and her determination to fulfil those desires. Her refusal of suitors she does not find attractive, her defiance of her father and the whole community is rendered with sympathy. In contrast with other rebellious young women of the period (Irén in Spider's Web's, for instance), here Kati's choice is truly her own. Her desire to marry for love does constitute a genuine defiance of pater and society.

There is textual evidence to show that what is at work is a privileging of a specifically female experience. To name just one example: in one scene we see a loose close-up of a woman breastfeeding her baby. Both mother and child are focused on the task, and the shot seems as natural as permitted by the presence of an intrusive mechanical apparatus and its crew. Admittedly, this could be easily read as the exoticization of the rural, which I call folksploitation, and which was typical of the Hungarian film industry of the 1930s. Indeed, in Hortobágy, a film made by an Austrian-born director with Swiss investment (Pálóczy Horváth reprinted in Sándor 1993, 153) and a Hungarian crew at about the same time and place as In the Palm of God, there is a similar image of a breastfeeding woman. There the effect is exploitative, and fits into a patriarchal ideology that sees women as vessels of reproduction. Inserted into a sequence of mating horses and storks, preceded by a shot of peasants milking ewes and followed by a shot of chicks in a nest waiting for the return of the parent bird, the filmic representation places the nursing mother within the animal realm. Höllering's shot is thus the exoticizing gesture of the patriarchal centre looking at the feminine margin. Riedl's shot of a nursing mother, contextualized not by animal, but community life, men and women at work on the joint enterprise of extracting food 
from the land, is a significantly different representation, and could be termed an 'intimate witnessing' (Thornham 2014) of a feminine experience.

And yet, In the Palm of God is not quite the piece of oppositional filmmaking the above might lead the reader to conclude it is. The decision to use mostly non-actors was unusual, but not without precedent. The film's uniqueness comes from its lack of stylistic and narrative coherence. Two experienced directors have advisor's credit on the film, something that was highly unusual in the Hungarian industry in the 1930s when shooting schedules were brief and crews were small. This suggests an effort to keep the director under control, and leads me to speculate that the shoot was not without conflict. This film is extraordinary in that it is a site of contestation, where the tussle between a suppressed and a dominant voice is writ large. It is apprehended not in stylistic or aesthetic fragmentation, but in cuts made to Riedl's text. Sequences that are alien to it, such as the sequence that glorifies the natural environment of the Hortobágy, have been inserted into the text. In other words this is a text that bears witness to the strength of resistance to a feminine voice in a male-dominated centre of production. In addition, the film's story set in a rural community focusing on what contemporary commentators and the dominant nationalist political elite called the simple honesty of Hungarian peasants, and its Hortobágy vignette, place it squarely within the period's state-approved nationalist filmmaking tradition.

We have concrete evidence of the radical nationalist vision of those involved in the making of In the Palm of God. Huzly sought to promote the film in an editorial published in his medical bulletin: "'Grape grows on the vine. Fathers have sons. And the land for which its children die - cannot die." The soldier son of a martyred horse-riding hero says these words to his mother under the national flag [...]' (reprinted in Magyar Film 19 August, 16). This is a catalogue of nationalist tropes, from the Hungarian military ideal through the thirst for martyrdom and a soil and blood-based concept of the nation to the reduction of women to patriotic vessels of reproduction. Huzly goes on: 'this film bears evidence of the importance of the peasant, $[\ldots]$ that ancient wellspring of national vigour' (ibid.). This may be the author responsible for the sequence that fawns over the beauty of the Hortobágy, and indeed, the script that survives is written, in parts, in much the same style. But it is hard to believe that it is the same hand that wrote the delicately observed scene, not included in the script, in which Kati and the cadet walk in the Buda hills. In the Palm of God may have adopted the perspective of an adolescent girl with a remarkable sensitivity and honesty, but Riedl was not the only person in a position of creative input. Huzly's voice can be isolated in outbreaks of nationalist tropes.

Huzly's input can be apprehended in another sequence. The reference may seem oblique, but the scenes set in Budapest can be clearly linked to the discourse of the anti-Semitic far right. Kati meets her love as she watches the changing of the guard outside the Regent Horthy's residence in the Castle district. The 'changing of the guard' was the euphemistic name for the expulsion of Jewish Hungarians from the economic and cultural life of the nation. ${ }^{\mathrm{xii}}$ It is a significant event in the film. The phrase itself features dozens of times in the first third of Huzly's script. In the film Kati and her aunt turn out to watch it, the cadet is training to join it, Kati's policeman uncle maintains the peace during its execution, and Kati and the cadet fall in love having been brought together by it. In light of the far right links of many senior members of the crew, particularly those of Huzly, it is fair to suggest that the on-screen changing of the guard should be read as a not unsympathetic reference to the broader off-screen movement for an anti-Semitic changing of the guard in Hungarian public life.

Ultimately, In the Palm of God can be understood as a minor production co-opted by a radical rightwing interest group in order to exploit a new marketplace in which the goalposts have been shifted in their favour.

\section{Light and Shadow: friends in high places}


The third film is Klára Tüdös's Light and Shadow. Of the three directors, Tüdős is the one we know most about. She was a versatile artist and entrepreneur. She was a costume designer for the Budapest Opera, and also worked as a set designer, and ballet choreographer (Erdélyi 1985, 73). She was an occasional theatre director and ran Pántlika, a popular fashion boutique, where she sold her own creations (Székely 1994, np). While Balázs and Riedl were relatively unknown in their time, Tüdős was a celebrated figure of Hungary's arts scene.

Tüdös's husband was Ferenc Zsindely, who occupied various ministerial positions from the late 1930s until 1944. As secretary of state in charge of the Prime Minister's Office for a while he filled one of the most senior positions in the political hierarchy of the time, and as the state-appointed head of the national film committee Országos Nemzeti Filmbizottság he had vast influence on the Hungarian film industry. ${ }^{\text {xiii }}$ During the 1940s, as the persecution of Jewish Hungarians gathered pace, Tüdős, a devout Calvinist, defied her husband by sheltering political opponents of the regime, as well as people persecuted for being Jews under the law. Tüdős was honoured by the Israeli Yad Vashem as 'Righteous Among the Nations' in 2001, one of only two Hungarian film industry figures to be recognized as such (the other being Katalin Karády). ${ }^{\text {xiv }}$ Because she was a prominent figure in the arts scene, and because of her marriage to a senior politician of the Horthy era, she had a difficult life after the war. Banished from Budapest, Tüdős and Zsindely lived as caretaker-gardeners in a lakeside resort near Balaton until his death in 1963, when she was finally permitted to return to the capital.

Light and Shadow tells the story of an actress, Mária (Elma Bulla). She is a great artist with an adoring public, loving husband and two beautiful children. We are introduced to her on stage as she is delivering the final soliloquy of Schiller's The Maid of Orleans. The curtain falls and she rushes to her husband off-stage: 'was I good?' she asks, needing external confirmation of her artistic achievement. As applause thunders on both sides of the curtain, her husband reassures her, she was good. Mária is a true artist, then. She thinks only of the quality of her performance, and cares little for the applause it brings. This will be contrasted effectively later in the film when Éva (Ilona Nagykovácsi), the young actress Mária decides to take under her wings, rushes off the stage after the performance of a bawdy number. She throws herself in the arms of the man who has left Mária for her, and squeals in delight: 'Can't you hear it? What success!'. Éva, whose number could not be further from the spirit of Mária's Saint Joan, does not care if what she does has artistic merit, as long as it earns applause.

In the first scenes of the film we see Mária tutoring Éva. The younger woman in return begins to seduce Mária's husband, Gábor (Andor Ajtay). After a party where Mária finally realizes the danger Éva represents to her marriage, tragedy strikes. The children go sailing on lake Balaton near the family's holiday villa. As she climbs up a hill to look for the children's sailboat on the water, she catches a glimpse of Gábor and Éva canoodling. A powerful storm descends as if from nowhere, and the shallow lake is transformed into a churning hell. As the storm brews, Mária and Gábor confront each other. 'You thought that for the sake of the children, I'd put up with it! But I won't! Not even for the children,' Mária rages. As if a higher power were listening (the film's message is that 'He' does listen intently), retribution follows swiftly for this discursive dereliction of maternal duty: the children drown. The shock is almost too great for Mária to bear. Her marriage to Gábor falls apart. He conducts an increasingly public affair with Éva, while Mária retires to the lakeside holiday villa. There she devotes her life to orphans and to the children of the destitute. Her once beautiful body becomes shrivelled and brittle as she literally gives her all to the children.

In the meantime Éva and Gábor lead a life of vice in Budapest. The old home that Mária and Gábor had shared is now a den of iniquity, with a portrait of Éva hanging in the salon. Éva is depicted in profile with her proud nose turned skyward and her lips sensuously parted. Her right hand, with talonlike fingers, cups her right breast. Her left breast is uncovered. This is patriarchal discourse at its most severe: the pert nipple of this breast never yet suckled by a child is a damning indictment. This is sinful eroticism, not the sacred beauty of a mother's child-worn body. This, we are left in no doubt, is a beauty 
that is in truth ugly, for it serves no purpose: it has not, nor will it reproduce and thus produce the nation. This is, in masculinist nationalist discourse, the superficially beautiful but in reality rotten body of the seductress who destroys the nation. And in considering this image, the film's central binary comes into sharp focus: Éva is Eve, man's downfall, the sinful woman unable to resist temptations of flesh and luxury. Mária is Mary, saviour of man, virginal yet life-giving. And the film ends with a reaffirmation of this binary: Éva, prematurely aged and with the ugliness of her soul inscribed in her ravaged body, is left bitter and lonely. By contrast Mária's careworn body brings Gábor to his senses. Finally he understands what the film suggests is the beauty of the corporeal inscription of self-sacrifice. As they find each other in old age, they look out over the lake that had claimed their children. In a gesture of macabre mawkishness the two dead children's spectral image appears, sailing their ghost yacht near the shores of the lake. This is not the mournful spectre of loss, however, but the cheerful promise of imminent reunion in heaven, an image whose broader significance is the chilling promise of a nation reunited in the ecstasy of collective martyrdom. ${ }^{\mathrm{xv}}$ (Figure 1.)

Here, too, a quick run-through of the credits is revealing. Some of the period's best were involved: the photographer was Hungary's foremost cinematographer of the period István Eiben. The exteriors were shot by Árpád Makay, whose virtuoso camerawork on the 1941 melodrama Egy asszony visszanéz/A Woman Looks Back (Géza Radványi) cemented his reputation as Eiben's brightest student. The film was edited by the prolific Zoltán Kerényi, and the music was composed by Ottó Vincze. They were all experienced 'safe hands'. Makay, Kerényi and Vincze made their breakthroughs in 1939, and all three can therefore be considered as owing their careers to the anti-Semitic purge of the industry. They were all involved in a number of radical nationalist productions, and they all have a revealing gap on their CVs after 1945, indicating that they were banned from making films after the war. ${ }^{\text {xvi }}$

In assessing Light and Shadow in her 1985 Filmkultúra article Erdélyi is not forgiving of the film's tone of dour zealotry, and her reading is often justifiably harsh. At times, however, she goes too far. There is a flavour of malice to her words, when she writes 'Tüdös was not satisfied with telling this sentimental story, she had ambitions of making art' (Erdélyi 1985, 73). The film is certainly mawkish, but it seems wrong to ridicule Tüdős's ambition. Erdélyi's comments on the film are heavily inflected by the ideology of the state socialist period, and her chief concern is with the film's apparent lack of sympathy for the poor, and its failure to condemn social and economic inequality. Her judgement is that the film celebrates the charitable rich and by contrast condemns the grasping poor. As we have seen, the reading that the film celebrates the rich by foregrounding Mária's use of her wealth to do good is supported by the text, but the complementary conclusion that the film vilifies the poor is wide of the mark. If we take a close look at the film's plot, we find a film that offers a powerful story of virtue and sin, beauty and ugliness, light and shadow. In keeping with the simplified world view of radical nationalism good is pitted against evil and a series of binary oppositions are at the heart of the narrative. However, the economic dimension of this series of binaries is to do with charity and greed, not wealth and poverty. Ultimately, Erdélyi's reading is undermined by the ideological perspective which she was compelled to make her own.

As my account of the film suggests Light and Shadow is an effective melodrama with relatively high production values and a dose of shrill piety. It would be offensive to attribute this to the input of the woman at the helm, just as it would be essentialist to read the film in light of its focus on the betrayed woman. There is certainly a focus on femininity and the role of women in society in the film, but as we have seen, this is more closely linked to Spider's Web's patriarchal discourse, than to In the Palm of God's happy coincidence of official ideology and ethnographic authenticity. Mária's trajectory cannot be claimed for feminism as a powerful positive model, or as a tragic and cathartic narrative. Neither is Éva's figure one that is usually associated with a film that shows sensitivity for the difficult role of women in a male-dominated world. The film's harsh judgement of Éva, and its vision of femininity rooted in the ideals of nurture, self-sacrifice and Christian love are, perhaps not so curiously, echoed in 
Tüdős's personal story. By sheltering those who were persecuted by the regime her husband served, Tüdös gave evidence of those same qualities of selflessness and courage that her film demands of its central female figures.

\section{Conclusions}

As discussed, the three films do not challenge the dominant discourse of their time and owe their release in large part to their success in hitting the right ideological notes. The different creative crews helped give a sense of the key differences between the three films and the distinct historical moments in which they were produced. In the case of Spider's Web we saw a diverse crew working together on a joint commercial enterprise. In the case of In the Palm of God a more seemingly homogenous crew was involved, but pursuing diverse goals, which ranged from the political, through the financial to the artistic. In the case of Light and Shadow a crew united in purpose to create a prestige production and a narrative that served the national(ist) interest. Furthermore, the need for product at a time of imbalance between output and demand played a part in ensuring that unconventional films had a chance of making it into cinemas. With the industry desperate for domestic product to satisfy protectionist quotas, but faced with a sharp drop in output, any film that satisfied increasingly limiting state-imposed criteria was approved for release.

The three films demonstrate the trajectory of the Hungarian industry in this period: moving from competition via a transitional period to a command economy. With the full participation of the state, the assets of a clearly defined but heterogeneous segment of the population ('the Jews') was expropriated by a small group. In the process, films made to satisfy demand and entertain the audience were replaced by films made by a state-controlled industry devoted to the top-down dissemination of official ideology. The first film, a light and breezy romantic comedy, was made when capital still had a major role in dictating the terms. The second, an ambitious high-concept film by an outsider, was made when the industry was in the process of a profound restructuring that saw established filmmakers cut out of the sector and untrained newcomers take their place. The third film was made when the new system was in full working order. At this time, access to the political elite eased the route from preproduction to exhibition.

The answer to the question probed by this article, namely why did women filmmakers emerge in pre-1945 Hungary, lies in the great upheavals that the country underwent in the aftermath of World War 1 . The war itself was followed by the traumatic redrawing of the borders, which created great economic and social problems. Then the Red Terror of the Communist uprising of 1919 was followed by White Terror and pogroms. The Great Depression had a big impact on Hungary and the 1930s were characterized by great economic ups and downs. These factors led to the progressive radicalization of public discourse and the national community as a whole as a formerly important multi-ethnic and multilingual regional power became a minor country suffering major economic, political and social crises. Throughout these upheavals gaps and fissures appeared in formerly rigid structures: new, increasingly precise regulation on the conditions of participation in cultural production meant that some hitherto excluded groups were up to a point able to overcome non-legislative obstacles. Balázs, Riedl and Tüdös seized their opportunity to realize their ambition. Their failure to follow up their films indicates the rapid consolidation of the Hungarian industry after the twin upheavals of the transition to sound, and the anti-Semitic purge.

All this suggests that the success of women directors can be linked to periods of upheaval. When we look at the global picture, we see a similar pattern of women directors making a breakthrough at times of profound change and/or crisis. Alice Guy, Dorothy Arzner, Esther Eng, Germaine Dulac and Leni Riefenstahl all achieved success at times of aesthetic experimentation, technological upheaval, and economic and political crises. However, the history of women's cinema is as yet fragmented. Many more practitioners, overlooked or excluded from male-dominated film histories, are yet to be 
'discovered' and put back into the history which they shaped as much as the next man. This article represents a small step towards the re-writing of film history by recognizing hitherto excluded bodies of work as belonging to film history proper. It also demonstrates the usefulness of the study of small, but long-established national cinemas - of which there are many in Central and Eastern Europe - to draw parallels with and illuminate global processes and film history as a whole.

\section{Notes on contributor}

Gábor Gergely is a lecturer in film studies at the University of Lincoln. He has recently completed a Leverhulme Trust-funded project on Hungarian popular film in 1931-44, and has a book forthcoming on the subject with Amsterdam University Press. In addition to his work on interwar and wartime Hungarian cinema, he has published on émigré actors in classical Hollywood (Foreign Devils, Peter Lang, 2012) and has written on the production of space in the MGM Tarzan films of Johnny Weissmuller.

\section{Acknowledgements}

I would like to acknowledge the invaluable help of Katalin Varga at the Hungarian film institute Magyar Nemzeti Digitális Archívum és Filmintézet (MaNDA) without whose help I would not have come across In the Palm of God. I would also like to thank Mónika Ongainé Juhász of the Mezökövesd municipal library Mezökövesdi Városi Könyvtár, and film conservationist Pál Pap of the Matyóföldi Alkotók és Müvészetpártolók Egyesülete.

This work was supported by the Leverhulme Trust [ECF-2012-29015].

\section{References}

Bingert, János. 1928. A mozgófényképüzemek és filmügyek rendészete, edited by Dr. Mihály Baik, Budapest: Magyar Mozi és Film.

Braham, Randolph L. 2000. The Politics of Genocide: the Holocaust in Hungary, Detroit: Wayne State University Press.

Erdélyi, Ágnes. 1985. 'Jegyzetek az első magyar rendezőnőkröl' Filmkultúra 8, 70-74.

Gaines, Jane. 2004. 'Film History and the Two Presents of Feminist Film Theory.' Cinema Journal 44 (1) 113-119 doi:10.1353/cj.2004.0045.

Gyurgyák, János. 2007. Ezzé lett magyar hazátok: a magyar nemzeteszme és nacionalizmus története, Budapest: Osiris.

Nemeskürty, István. 1965. A meseautó utasai, Budapest: Magvető.

Pintér, Judit. and Záhonyi-Ábel, Márk. eds. 2013. Ember a havason - Szöts István 100, Budapest:

Kosztolányi Dezső Kávéház Kulturális Alapítvány.

Sándor, Tibor. 1992. Őrségváltás: a Magyar film és a szélsőjobboldal a harmincas-negyvenes években, Budapest: Magyar Filmintézet.

Székely, György ed. 1994. Magyar Színházmüvészeti Lexikon, Budapest: Akadémiai Kiadó

Thornham, Sue. 2014. “'Not a country at all': alternative genealogies and Wuthering Heights” Paper presented at the annual 'Doing Women's Film and TV History' conference, University of East Anglia, April 10-12.

Tönsmeyer, Tajana. 2008. 'The Robbery of Jewish Property in Eastern European States Allied with Nazi Germany' in Robbery and Restitution: the Conflict over Jewish Property in Europe, edited by Martin Dean, Constantin Goschler and Philipp Ther, Oxford: Berghahn.

Turda, Marius. 2010. Modernism and Eugenics, Basingstoke: Palgrave Macmillan. Vajdovich, Györgyi. 2013. 'Ideológiai üzenet az 1939-1944 közötti magyar filmekben - A magyar "népi film"' in Metropolis, 17 (2) 68-76. 
Varga, Balázs. ed. 1999. Hungarian Feature Films 1931-1998 2 $2^{\text {nd }}$, extended and revised edition Budapest: Magyar Filmintézet.

\footnotetext{
${ }^{\mathrm{i}}$ All translations, including titles of films, by the author unless otherwise indicated.

ii Its official name is Magyar Nemzeti Digitális Archívum és Filmintézet (MaNDA).

iii In the immediate aftermath of the suppression of the Hungarian communist revolution of 1919, cinema operator licences were introduced. Existing and prospective cinema owners were compelled to apply for a licence, to be issued by the Ministry of the Interior. The licences were awarded to applicants who were deemed fit and proper (Sándor 1992, 35-6). Although the statutory instrument 8454/1920 M.E. under which the licences were issued avoided making explicit reference to race or religion, its implementation was anti-Semitic, and the measure's aim was to exclude Jewish Hungarians from the industry (ibid.).

${ }^{\text {iv }}$ See www.1000ev.hu for a digital database of Hungarian laws enacted between 1000 and 2003. The database was published by Wolters Kluwer, Budapest for CompLex.

${ }^{v}$ It is important to note that the loss of a large number of experienced market players of any stripe would leave any sector reeling. No inference should be drawn about the Jewishness of the industry pre-1938 on the basis of the law's impact.

vi For example scriptwriting competitions (see Magyar Film February 2, 1942, 8).

vii See editorial on the work of the censorship committee by national film censorship committee chairman Alfréd Szölőssy in Magyar Film December 28, 1940. See also Bingert (1928).

viii $\mathrm{He}$ is sometimes referred to as a miracle doctor, suggesting that he held unconventional views, or may have practiced homeopathy. He published books on blood pressure and blood sugar levels, anaemia, the effects of smoking and on healthy eating and healthy living. He was a member of the eugenics society Magyar Nemzetpolitikai Társaság (Hungarian National Policy Society), a standard-bearer of Hungarian racial nationalism, and participated in the establishment of the Film Chamber.

ix The Turul Szövetség Bajtársak Szépmíves Egyesülete or the Comrades' Fine Crafts Circle of the Turul Alliance was a radical nationalist, anti-Semitic organization. The turul, a mythical/apocryphal bird of prey, was chosen by many extreme rightwing organizations as their symbol in the early twentieth century.

${ }^{x}$ The credit sequence has been destroyed and the cast list was reprinted by Magyar Film without character names. Anecdotal evidence relayed by Pál Pap suggests that Marika Csuhai was the only daughter of the real Csuhai family, and two other girls were recruited from the village to play the other two daughters. They were Kata Szőcsi and Terus Gyenes. Going on the suspicion that the players' real given names were used, Kata Szőcsi is most likely to have played Kati.

xi I spoke with Pál Pap over the telephone on several occasions in 2013. Pap revealed that local knowledge had it that Riedl had a cameo in the film as an old woman. It is possible, if the story is true, that she may be one of the gossiping women in this scene.

xii A 1942 book by István Hegedüs, published by Stádium in Budapest, charted the 'progress' of anti-Jewish measures under the title Örségváltás/Changing of the Guard.

xiii His appointment was announced in Magyar Film April 29, 1939.

xiv http://db.yadvashem.org/righteous/family.html?language=en\&itemId=9770229 accessed on 8 January, 2015.

${ }^{x v}$ Hungarian nationalist discourse through the nineteenth and twentieth centuries was preoccupied with the idea of nemzethalál or death of the nation. For more on the concept in Hungarian see Gyurgyák 2007. In English see Turda 2010.

xvi An account of the work of post-war vetting committees set up by the Hungarian Free Trade Union of Actors is a major gap in Hungarian (film) historiography.
} 